\title{
sciendo
}

\section{Transfer of seat within European Union. The latest developments on cross-border conversions, mergers and divisions of companies}

\author{
Ovidiu Ioan DUMITRU \\ Bucharest University of Economic Studies, Bucharest, Romania \\ ovidiu.dumitru@drept.ase.ro
}

\begin{abstract}
Transfer of seat of companies remains one of the debated issues at European Union level as more and more cross border transactions are taking place and the shareholders try to take advantage of the rights of free movement provided by the treaties. The recent caselaw brought the European Union in a difficult position, having to accept the existing lacks in the treaty's provisions and come with specific legislation to cover the consequences raised after Polbud case. The caselaw on transfer of seat of companies from one member state to another was not very complex and numerous at the beginning, but became incisive with the development of the internal market and increase of cross-border transactions, becoming more open towards the acceptance of the freedom of establishment in most cases of transfer, forcing the national company law, especially the rules on conflict of law, to encounter a new challenge in the harmonisation of the provisions related to incorporation, functioning, merger/division/conversion or the creation of secondary establishments. This article wants to be an overview on the reaction of the European Union, especially through the latest Directive in the field, Directive on cross-border conversions, mergers and divisions was adopted by the European Parliament and the Council (Directive (EU) 2019/2121), but taking into account the caselaw in the field and trying to project future evolution of the new provisions.
\end{abstract}

Keywords: transfer of seat, merger, division, cross-border conversion, company law.

\section{Introduction}

The transfer of seat of companies within the Single European Market has been a challenging process in the last period, with many decisions of the Court of Justice of the European Union switching from one to other interpretation of the articles (second paragraph of article 49 and article 54) provided by the Treaty on the Functioning of the European Union, by that opening to new opportunities for companies to increase their growth and compute capabilities, and the Union's legislative initiatives in the field, coming to embrace the existing dynamism in regard to changing the place of activity from one to another member state (Khan, 2011: 847).

The latest act issued by the institutions for the fulfilment of the goals raised by the caselaw in the field of transfer of seat of companies was the Directive 2019/2121 of the European Parliament and of the Council from 27 November 2019 amending the Directive 2017/1132 as regards cross-border conversions, mergers and divisions which came as a reaction os the lateness development of the caselaw, especially the Polbud case (C-106/16).

This paper tries to present a short overview of the latest results of this complex process of legislating the transfer of seat, either by the caselaw or the normative acts in the field, firstly by presenting how the Court of Justice of the European Union understood to provide interpretations of the treaty provisions in different contexts and, secondly, by reviewing the main new elements brought by the amending Directive 2019/2121 still to be implemented by the majority of the member states, including the Romania, which plans to have a proposal by September 2022 .

It is clear that the development of the Single European Market forced a fulfilment of a better and easier transfer of seat of companies from a member state to another as the business es are 
adapting to the environment, going with the clients and resources and needing to adjust better their own structure for their integration into a bigger, but changeable, market (Dumitru, 2020, 71-73).

The member states, on the other hand, had, always, the tendency to overprotect their own markets and business environments, distrusting the foreign companies in insuring a conservation of the national values and standards, especially in the areas referring to the interests of company's employees, creditors or other stakeholders and, as a consequence, overusing their right to set the requirements for the existence of the companies, provided by art. 54 of TFUE and the caselaw. (Ringe, 2013: 233)

\section{Transfer of seat, accommodation of European provisions with the national rules on company law}

The company is a legal person having as main objective gaining profit for its shareholders and it does that by entering in legal relations with other persons and performing a commercial activity, its legal existence being one of "a creature of the national legal system" (Daily Mail case), the one which delivers its legal status, capacity and administration rules. But what happens when that specific legal person wants to merge with another coming from a different legal system? What should happen to the existence of the company if it wants to perform its activities in a different jurisdiction? How should react the host state to the intrusion of such companies? It may deal in two ways with that, either by accepting the existence of the foreign company solely by it being created in a foreign state or start analyzing and determining its status by applying its own domestic company law provisions.

There are different ways to solve the above issue, most jurisdictions having national private law or conflict of law rules which are determining if the national or foreign law is to be applied to the respective company or its relations, specifically determining the "lex societatis", the law governing issues like the formation, the functioning, changing status or even the end of that company. There can be cases in which the host state may not recognize the foreign company and apply domestic rules for all aspects of the company's legal status or even recognizing it, but applying its own rules on certain aspects of the company's life (Ringe, 2013, 234).

A very important issue to be solved is the connecting factor, meaning the element which brings the foreign company in relation to the host state and by that start questioning the applicable national substantive law for the respective legal person, determining if the transfer of seat is allowed or not. (Fabris, 2019: 108). These connecting factors are the ones raising questions on how much the domestic law will apply to a company or how much is keeping its own form and this is important in defining the so-called "free movement of companies", an abstract view on the activity of a company in more national markets and jurisdictions. As a conclusion, we may say that the establishing of the connecting factors is strictly about the establishment and movement of companies within the Single Market, as the two treaty provisions are granting.

Moreover, next to the identification of the connecting factors, important is how the host states are defining the trigger elements which are leading to the respective national jurisdiction or not and, in time, it was noticed that there was no common rule on that. The national provisions have defined differently the trigger elements and limit of application of domestic or foreign company law.

The above issues need to be analyzed and understood in relation to the process of free movement of companies within the market, a right provided by the treaty, but raising questions when having to be connected to the divergence of national company laws. 
In order to understand how the issues were solved by the European legislator and caselaw, we must overview how the host states are reacting to company's entrance and how the home states are treating the exit from their jurisdiction. One way should be based on the reciprocal recognition of the national company law, but, in time, there were established two important theories in relation to the way it is decided which law to apply to the respective moving company, the "incorporation" and "real seat" doctrines. (Dumitru, 2020, 77-79)

We can notice, after overviewing the list of states and their approaches, that we have a split in two of the ones choosing the incorporation theory versus the real seat approach, still finding some where some forms of mixed choice being available.

States like United Kingdom, Ireland, Denmark, Netherlands, Sweden, Finland, Malta and most of the East European states like Romania, Bulgaria, Croatia are using, as rule of private international private law, the incorporation theory by which the company is a creature of the national law where it was incorporated, a choice which didn't raise so many issues in the free movement of the companies as it is a clearer criterion in the recognition of the law applicable.

In all these jurisdictions, the validity of formation, its legal personality, legal capacity and even the functioning rules are determined in accordance with the legal provision from the state where it is mostly connected and it claims its incorporation. (Wymeersch, 2003, 9)

On the other hand, states like Germany, Austria, Belgium, Luxembourg, Greece, Portugal and the Northern East European countries, Latvia, Lithuania and Estonia have decided to use the real seat doctrine which gives raise to some issues in relation to transfer of seat, especially in cases of companies coming from states with incorporation doctrines applied, as the hosting state is not recognizing the law of the moving company as being the one of the place of incorporation, but the one with which the company is mostly connected. Most of the jurisdiction are referring, the German was the most explicit in it caselaw, when providing the connecting factors, to main place of activity or place where is the central management. (Ebke, 2002, 1027)

In relation to migration of companies from one state to another, the second doctrine raises some issues as, in a restrictive application of the principle, the consequence for a company which decides to transfer in a new jurisdiction and by that, change its real seat due to more connecting factors to the new host jurisdiction, being the ceasing of the activity and even its existence if it doesn't fulfil the new requirements. The real seat doctrine restrains founders from selecting the national law applicable to their companies.

The incorporation doctrines jurisdictions are seen too open to "law shopping" as it allows the founders to establish the legal regime of the company no matter how many times they are changing its functioning environment. On the other hand, the real seat doctrine prohibits this possibility, being based more on public policy over the will of the parties and correlating the company with the legal system it is mostly connected, but it may, also, raise questions of identifying a unique jurisdiction, especially nowadays, when the decisional process is transferring online and the activities are present constantly in more states, leading to a need of flexible corporate processes.

The application of real seat doctrine, no matter the way those defining the connecting factors, is restricting the founders and managers of companies to operate freely within the Single European Market, but it was noticed, in the evolution of the caselaw in the field, a strange dynamic in relation with states' reaction to the provisions from the Treaty on Functioning of the European Union (Lombardo, 2019, 30). 


\section{Transfer of seat. Treaty provisions}

The treaty provisions on transfer of seat of companies are not many and diverse, they are only two main ones, article 49 and article 54 Treaty on Functioning of the European Union (TFEU).

Article 49 TFEU introduced the duty for a Member State not to restrict the right of establishment of individuals from another members state: "Within the framework of the provisions set out below, restrictions on the freedom of establishment of nationals of a Member State in the territory of another Member State shall be prohibited. Such prohibition shall also apply to restrictions on the setting-up of agencies, branches or subsidiaries by nationals of any Member State established in the territory of any Member State”.

This first paragraph of the article 49 confers two main rights to the nationals:

1. To setup individual commercial activities and companies/firms in other member states - primary establishment

2. If already established, to setup agencies, branches or subsidiaries in any members state secondary establishment

The second paragraph of the article develops what was provided by the first one by indicating that the "Freedom of establishment shall include the right to take up and pursue activities as self-employed persons and to set up and manage undertakings, in particular companies or firms within the meaning of the second paragraph of Article 54, under the conditions laid down for its own nationals by the law of the country where such establishment is effected, subject to the provisions of the Chapter relating to capital." relating it to the other provision of the treaty, article 54, which extends the rule to "companies or firms formed in accordance with the law of a Member State and having their registered office, central administration or principal place of business within the Union shall, for the purposes of this Chapter, be treated in the same way as natural persons who are nationals of Member States". But what do you understand by companies? The treaty tries in the second paragraph of the above article to explain that "Companies or firms' means companies or firms constituted under civil or commercial law, including cooperative societies, and other legal persons governed by public or private law, save for those which are non-profit-making”.

Article 54 TFEU clearly limits the sphere of the national rules on private international law, providing for the companies the right of freedom of establishment, just as it is conferred to individuals in article 49 TFEU. The conditionality for companies to make use of such a right is also indicated by article 54 TFEU and is related to more connecting factors, the first which is the strongest one is that the formation of the respective company to take place in a member state and for the second we have a list of three unclear ones: to have registered office, to have the central administration or to have a principal place of business within the European Union. We have to admit that each member state has its own national company law with its own sphere of legal persons and interpretation on the law applicable to them and the caselaw in the field shows the complicated life between the rights provided the treaties and the dynamic national provisions, especially in the jurisdictions where the real seat theory has been chosen as the one applicable.

As the European legislator failed in 1968 clarifying how the freedom of establishment should be made use by the companies and accepted by the member states, in the repealed "Convention on the mutual recognition of companies and bodies corporate", the clarification came from the caselaw. (Khan, 2011: 850). Moreover, the European Court of Justice issued even a new form of freedom of establishment in the situation of lack of recognition because it happens in the same state and, in time, pressured for a harmonization process which culminated with the latest proposal on cross-border conversions, mergers and divisions which was adopted by the European 
Parliament and the Council, the Directive (EU) 2019/2121 amending the Directive 2017/1132 as regards cross-border conversions, mergers and divisions.

\section{Evolution of transfer of seat in the European case law}

In order to understand better the current status of transfer of seat of companies and how the European Union wants to harmonize this field, we need to go through the tumultuous evolution of the caselaw in this field, from the first cases which are identifying the essentials of freedom of establishment, Reynes v. Begium (case 2/74) or Segers (case 79/85), to the cases which established the principles for primary and secondary establishment for companies with the internal market, cases like Daily Mail (case C81/87), Centros (Case C 212/97), later ones like Uberseering (Case C208/00), Inspire Art (case C167/01), Sevic Systems AG (case C-411), Cartesio (case C-210/06) or Vale (case C-378/10) to the latest that influenced fundamentally how the European legislator sees now the issue, Polbud (case C-106/16), a list by which analysis we can discover different interpretations of the Court, some even considered opposite, but explained by the sensitive relation of European legislation with the national company law, reason to be analyzed and correlated with the existing legislative instruments.

The first case which raised questions in relation to freedom of establishment of individuals with European Union and offered an interpretation of the treaty provisions was case 2/74, Reyners v. Belgium (Craig, de Burca, 2020).

The main question addressed to the Court was whether the treaty article on freedom of establishment was directly effective, so to confer rights on individual or just pressuring for the implementation of treaty and create provisions on mutual recognition.

Mr. Reyners, born and educated in Belgium, qualified as avocat, claimed the admission in the Belgian Bar, but he was refused because of his Dutch citizenship and the question was if what is now article 49 TFEU offered to dr. Reyners the right to establish a law practice in Belgium?

The European Court of Justice held that the restriction imposed for the admission in the Bar was contrary to what is now article 49 and article 18 (non-discrimination) both being directly effective

The Conseil d'Etat addressed the European Court of Justice and asked whether the legal profession of avocat was wholly exempt under the current article 49 official authority exception given that part of the business was concerned with exercise of official authority or only those activities which are related to the respective profession, based on what is now article 51 TFEU which provides: "The provisions of this Chapter shall not apply, so far as any given Member State is concerned, to activities which in that State are connected, even occasionally, with the exercise of official authority".

The Court held that "most typical activities" of the profession of avocat are consultancy, assistance and representation of the client which are not necessarily "involve a direct and specific connection with exercise of official authority" and was possible to be exercised in a separate way.

By this decision was clearly stated the direct effectives of the freedom of establishment and non-discrimination in the conditions for establishment, the Court having to solve also the question raised in relation to the indication that what is now article 49 needed for its application a certain implementation process.

The second important case bringing essential elements of the freedom of establishment, but also considerate the main one which offered the conditions for the members states to follow in order not to "hinder or make less attractive" the exercise this freedom is Gebhard, case C-55/94. 
Mr. Gebhard was accused by the Chamber of Lawyers of Milan of not following the provisions of the Italian Law No. 31 of 9th February 1982 concerning the supply of services and establishment of activities by part of lawyers of a Member State. Dr. Gebhard was a German lawyer, having his residency in Italy, who was not a member of the Italian Bar, but was practicing as an associate lawyer in a bigger law firm and decided to open his own office and practice on his own as "avvocato" even representing clients in court.

Gerhard reacted and contested indicating that Italy failed to implement the European guidelines into its national law, specifically in this case, the ones providing the freedom of establishment of law practice.

The European Court of Justice held that the members states may impose certain conditions for the access in certain professions which have a national organization, ethics, special qualifications, as there it is not a common agreement on recognition, but, also, issued a test by indicating that those national measures should not "hinder or make less attractive the exercise of fundamental freedoms guaranteed by the treaty" and they should fulfil four conditions:

"- they must be applied in a non-discriminatory manner;

- they must be justified by imperative requirements in the general interests;

- they must be suitable for securing the attainment of the objective which they wish to pursue;

- must not go beyond what is necessary in order to attain it."

Reyners and Genhard cases were the ones which established the main features of the freedom of establishment, building a foundation for the future cases to come in the area of transfer of seat of companies.

In relation to freedom of establishment of the companies within the European Union, the evolution of the caselaw was atypical in the sense that there were interpretations of the relation company - state which today might be seen forced, most of them contributing to the consolidation of idea that law shopping was not in accordance with the main provisions of the treaty, still having sufficient decisions which went towards something else.

The main case that created some problems for the fans of free movement of companies was Daily Mail case (case 81/87 - R (Daily Mail and General Trust plc) v HM Treasury and Commissioners of Inland Revenue (1988) (Craig, de Burca, 2020), where a question was addressed to the European Court of Justice as the approval required based ok UK tax registration for a transfer of residence of a British company to Netherlands was in accordance with the principle enacted by the treaty.

Daily Mail intended to transfer its central management and control to Netherlands, having in its intention to establish a tax residency in the new state, sell a part of the assets and buy its own shares and register then some substantial capital gains, taxable on UK legislation. This operation required a special approval from the Treasury, which imposed the sale of the assets and payment of the tax in order to issue it, so Daily Mail understood to address the High Court indicating that the European provisions granted the right of transfer without prior consent from the hosting state.

The Court of Justice held that TFEU article 49 did not apply, and so the rules requiring UK Treasury permission could operate. Moreover, it concluded that given the diversity of national rules about the factor connecting a company to the respective territory for the purposes of incorporation and the many different view of European jurisdictions on transfer of seat, companies cannot rely on articles 49 and 54, stating that "unlike natural persons, companies are creatures of the law and, in the present state of Community law, creatures of national law"

The Court's solution in Daily Mail case was a debated a lot as it was the one empowering the States in their defensive attitude, but many authors consider it ambiguous (Gerner-Beuerle et 
al., 2018,9) as it was referring only to companies existing for tax reasons, freedom of establishment prohibiting the host member state from "hindering the establishment in another Member State of one of its nationals or of a company incorporated under its legislation" (Mucciarelli, 2008, 268).

Another case which may be considered a milestone in the evolution of the freedom of establishment was Centros (Behrens, 2000, 125), one that we may consider changing the view expressed by the Court in Daily mail case, but not necessarily overruling it (Wulf-Henning, 2003, 189-190).

The case is about two Danes citizens who created in UK a company called Centros Ltd., which from the beginning the company was intended to activate only in Denmark, the incorporation taking place for the avoidance of the minimum legal capital requirement for Danish limited liability companies. The Danish trade registry reacted and declared this operation an unlawful avoidance of the Danish minimum legal capital rules and, as a consequence, it rejected the incorporation of a company's branch office in Denmark.

The case landed on the European Court of Justice table and in the answer to the questions addressed by reference for preliminary ruling, it ruled that the Member States are prohibited from discriminating against this company on the ground that it was formed in accordance with the law of another member state in which it has its registered office but does not carry on any business and also that a state is not authorized to restrict freedom of establishment on the ground of protecting creditors or preventing fraud if there are other ways of countering fraud or protecting creditors.

Later, the things were getting even more interesting with some decisions on other types of limitation of transfer of seat, especially in real seat doctrine countries. One of those cases was Überseering case, where a Dutch company contracted a German construction company NCC, for works on one of its buildings, and NCC asked in court for payment of the works, but as the performance was unsatisfactory for Uberseering, the latter proceeded with legal actions against NCC. The company's legal proceedings were dismissed on two occasions, on the grounds that Uberseering lacked the legal capacity in Germany, a case in which a company pretends to transfer its actual center of administration from Netherlands, an incorporation state, to Germany, a real seat state, but continuing to be ruled by Dutch law.

As the German courts stated that the company had no legal capacity as it was not following the required formation formalities under German law, the European Court of Justice had to explain that a company created in a Member State has the right to move its real seat from the state of incorporation to another EU member state without losing its legal status as a corporate entity under the law of its origin state and by that overturning some of the points of view launched in Daily Mail case (Wulf-Henning, 200, 205-208, Fabris, 2019, 116).

Other case with a restriction, this time brought by the national legislator with the intention of harmonization, but decided by the court that represented a breach of the freedom of establishment is Inspire Act case, this time in Netherlands, an incorporation doctrine state.

In this case, a Dutch national created a company called Inspire Art Ltd under the laws of England and Wales and requested the registration of the company's Dutch branch office at the trade registry in the Netherlands, intending to start in Amsterdam the activity of an art studio. The Dutch authority considered that the situation was the one provided for foreign entities registered in the Netherlands (based on the Law on Formally Foreign Companies from 1997) which leaded to different duties like using in the firm a wording indicating the foreign origin of the company, having to contribute to legal capital in accordance to Dutch rules. The company Inspire Act claimed that the above national rules are representing a restriction of the right to freedom of establishment provider by article $49 \mathrm{TFEU}$.

DOI: 10.2478/picbe-2021-0085, pp. 917-929, ISSN 2558-9652 |

Proceedings of the $15^{\text {th }}$ International Conference on Business Excellence 2021 
Next to opening secondary establishments, there were, in time, problems also with the process or mergers or acquisitions between companies from different Member States and the first case raiding such an issue was Sevic case from 2005 in which two companies, one from Germany and the other from Luxembourg wanted to merge in only one and transfer the seat of one of the merging companies, but the German authorities refused the application due to a national provision which allowed such operation only between companies incorporated in Germany.

The solution offered by the European Court of Justice in Sevic case is defined the new area of cross-border mergers, the Court clearly stating that mergers between companies from different Members States represent an essential element for the creation and development of the single market being covered by the freedom of establishment.

The European Court of Justice held that the national provisions were not compatible with the European law and a company from another Member State is to be respected not only as a legal person party in a legal proceeding, but it has to be recognized as subject of company law of its state of incorporation.

With all the evolution of the caselaw and even after a change of view of the Court on the impediments on transfer of seat, another case would reinstate the conclusions from Daily Mail case and rearranged the compatibility of the real seat theory with freedom of establishment (Borg-Barthet, 2009, 1020-1022). This was Cartesio case in which Cartesio Bt, a company formed in Hungary as a limited partnership in 2010, intended to move its real seat to Italy, with no change in the applicable law (Gerner-Beuerle, Schillig, 2010, 322-323).

The specialized Court, having to register the operation, declined the registration of the new Italian seat in the registry, claiming that such a transfer was not allowed according to the legislation in Hungary, since in order to transfer its seat, a company has to liquidate, losing its legal existence. (Stoican, 2020, 67).

The European Court's response was the following:

"companies are creatures of national law and exist only by virtue of the national legislation which determines its incorporation and functioning"

"the question whether the company is faced with a restriction on the freedom of establishment [...] can arise only if it has been established [...] that the company actually has a right to that freedom. "That power includes the possibility ... not to permit a company ... to retain that status if the company intends to reorganize itself in another Member State..."

A case which is a mirrored one from Cartesio, related this time to a merger, is VALE Épatésix aft case, with a cross-border conversion of a company established under Italian law, VALE Constrain Sol, into a company incorporated under Hungarian law, VALE Éputésir ft. The Italian law provided that it is possible for a company to convert into a company established under foreign law, but the Hungarian law clearly indicated that only companies incorporated under the law of Hungary are allowed to convert.

The European Court of Justice Court held that a Member State may restrict a company governed by its own national law to keep its legal status if that company intends to move its seat to another jurisdiction and by that destroying the connecting factor required under the national law of the Member State of incorporation. Still, the state of origin cannot prevent a company from converting itself into a another governed by the law of the other Member State (Borg-Berthed, J. 2013, p. 503).

The case which completed the puzzle (Faris, 2019, 121) and "forced" the European legislator to come with a proposal on conversions of companies, offering some clarity (Fillers, 2020, 588-589), was Poldi case where Wykonawstwo sp. z o.o. ('Polbud') was a private limited 
liability company incorporated under Polish law and established in Łącko. In September 2011, its shareholders decided to transfer the 'company's seat' to Luxembourg, change its name, but keep the legal personality of the company.

The company was registered in the Luxembourg Companies Register in 2013 and, as a consequence, it requested the removal from the Polish Trade Registry, but the application was rejected. Polbud reacted and filed a final appeal at the Supreme Court of Poland, claiming that on the day of transfer to Luxembourg, it had changed its legal status and transform from a Polish company one under the Luxembourg law.

The European Court of justice was asked, by reference for preliminary ruling, to answer if there was any infringement of the freedom of establishment, so it decided that a situation in which a company created in accordance with the law of a Member State wants to convert itself into other company from another Member State, with the condition that the entering state checks the existence of the connecting factors, falls within the scope of freedom of establishment, even though that company conducts its main, if not entire, business in the first Member State (Fillers, 2020, 573-575).

Moreover, the Court notices that the Polish law states that a company may transfer to another state without losing its legal personality and remove its firm from the national registry, but only if it has been liquidated before and by requiring this, it impedes the cross-border conversion of the company representing a restriction on freedom of establishment.

\section{The latest developments of transfer of seat in European Union, reaction to case law - Directive 2019/2121}

With its groundbreaking decision, the European Court of Justice opened the doors for a better corporate mobility, the main reason being its opinion that the freedom of establishment also includes the right to change into a legal form of another EU country without having to dissolve the company in the country of origin (Soegaard, 2018, 21-24).

Still, despite the decisions, companies are facing continuous hardships in implementing cross-border projects, mainly due to the discrepancies from national rules and lack of a clear and reliable legal framework.

In order to compensate this regulatory shortfall and to create higher legal security, at EU level was designed a legal framework for cross-border conversions in the form of Directive (EU) 2019/2121 of the European Parliament and of the Council amending Directive (EU) 2017/1132 as regards cross-border conversions, mergers and divisions. The Directive designs a legal framework for European corporations related to the reorganization measures with cross-border implications, which may lead to a change in the law applicable to the respective entity (Dumitru, 2020, 91-93).

The Directive entered into force on 1 January 2020 and has to be implemented, as it is a Directive, by 31 January 2023. However, since this is the first time that there is a European legal framework for cross-border conversions and divisions, next to the cross-border mergers already in place in European legislation, the Directive started being directly relevant to companies from the moment of entering into force, the academic world and the professionals starting commenting on future development of the new provisions.

The Directive which is updating and amending an existing one, especially due to the new evolution of the caselaw, is just starting to be implemented and many Member States are still analyzing the pieces of legislation they have to amend nationally in order to fulfil the objectives established by the directive (Chirieac, 2020: 281). 
We are analyzing this Directive in order to explain how the European legislator reacted to the tumultuous life of the freedom of establishment in the past years, but it comes and it places itself on a table where have been implemented and applied several fundamental European acts related to company law, Starting with Directive 2017/1132 regarding cross-border mergers which it is also the one amended by the current one, and continuing with the other Directive from the company law package launched in 2019, Directive (EU) 2019/1151 of the European Parliament and of the Council of 20 June 2019 amending Directive (EU) 2017/1132 as regards the use of digital tools and processes in company law, but on a stable foundation build by the company law Directives issued starting from 60’s (Sánchez Barrios, 2020: 234-235).

In relation to the present status of implementation, after a short overview over the national legal systems, we have to admit that only several Member States have started preparing and are either in the stage of public debate on the way to transpose or they launched the process of thesis elaboration, but the majority are still investigating the Directive in order to elaborate proposals.

Most of the Member States started the public consultation procedure in order to decide which are the best ways of transposition, but it seems it isn't an easy job, as the national company law is composed of several pieces of legislation, some more general, like codes, others special rules on companies or cross-border operations.

As an example, we can take Ireland, which launched the consultation in august 2020 and where there are provisions on both national mergers and divisions in Part 9 of the Companies Act 2014, entitled "Reorganisations, Acquisitions, Mergers and Divisions." and Statutory Instrument 157/2008, which refers to as the European Communities Cross Border Mergers) Regulations 2008 (as amended by Statutory Instrument 306/2011), a proposal having to be delivered by amending the above legislation.

If we look at the Spanish legislators, we can notice that they are analyzing to amend the national law no. 3/2009 regarding the structural transformations of companies, which has a chapter referring to cross border Mergers (articles 54 to 67), but taking into account that the European act regulates also in matters related to procedural law, it might be necessary to adjust also the Organic Law of Judicial Power where it is provided the center of rules referring to judicial competence. (García, 2020, 8).

In Romania, the institution responsible for the Transposition, Ministry of Justice, has planned to come with a proposal amending law 31/1990, the law on Companies, by September 2022, the goal being for this act to be adopted by the Romanian Parliament in January 2023.

In the preamble of the Directive, it is clearly stated that this text is a result of the active development of the case-law in the field, and it intends to offer better opportunities to companies and by that to attain the objective to shape an internal market without internal borders for companies, but we have to wait and observe how the member States are going to fulfil this main objective, as now they are still confused how to correlate the existing national legislation on reorganization, merger, divisions or cross-border mergers, in most of the jurisdictions regulated in different acts, with the new provisions enacted by Directive 2019/2121.

One of the main new institutions brought by this Directive, as a reaction to the Polbud case, is the implementation of the conversion of companies, which it is defined as being an operation whereby a company, without being dissolved or wound up or going into liquidation, converts the legal form under which it is registered in a departure Member State into a legal form of the destination Member State, ....., and transfers at least its registered office to the destination Member State, while retaining its legal personality (Art $86 b)$. 
We can understand from the definition of conversions that the process of transfer of company implies a transformation from the legal form from one state to other, at least the change of the registered office, but all without losing its legal personality, the debated issue in Polbud case (Ene, 2019, 56).

As scope, the act provides in its first Chapter that it applies to the limited liability companies from a Member State transforming in similar forms in another one, with the connecting factors with the host state are the ones provided by the treaty in relation to freedom of establishment, the registered office, central administration or main activity, with a list of several exceptions like companies where "collective investment of capital provided by the public" or "which operates on the principle of risk-spreading", are not subject of liquidation, insolvency or crisis prevention, the conversion being seen as a solution for those who want to shift a current.

A very important benefit of the new created operation is the fact that since the company does not lose its legal personality, tit's assets and liabilities together with the agreements already concluded will be transferred to the new entity.

The Directive provides that in order to proceed with the process there has to be obtained a pre-conversion certificate, like a proof of compliance with the home state conditions, with the procedure governed by the home state through a Court, notary or other relevant authority. The Application for pre-conversion certificate has to come together with other documents of the company like: draft terms for the conversion, a report of the management, a report of an independent expert, approval of the general meeting or other information like number of employees, subsidiaries or fulfilment of public duties (art. $86 \mathrm{~m}$ ).

In relation to the documents requested in the application for a pre-conversion certificate, we can resume that the Directive is guiding the national authorities towards acknowledging the will of the owners in transferring the business, the main acts to be concluded in this direction being: 1) the draft terms of cross-border conversions provided by article $86 \mathrm{~d}$, very similar to a merger plan, with the indication of the legal forms, present and future, instrument of constitution, timetable of the process and rights and safeguards for creditors, management, employees;

2) the report of the administrative and management body for owners and employees explaining the "legal and economic aspects of the cross-border conversion" provided by article 86 e.;

3) a special report on the draft of the conversion performed by an independent expert indicating, especially, if the "method or methods used are adequate for the assessment of the cash compensation";

4) approval of the draft of the cross-border conversion by the general meeting, after hearing the reports and the employees' opinion with a minimum quorum of attendance of $2 / 3$ of the members, but no more than $90 \%$ and the voting quorum similar to the ones provided for cross-border Mergers.

Amongst the compelling provisions included in the Directive is the aspect referring to abuse prevention, conversions couldn't take place in case it pursued illegal or fraudulent demeanours which can bypass Union or national law, an obligation being imposed on Member States to ensure that their competent authority will not issue the confirmatory certificate regarding compliance with legal obligations if it is established that the operation has been set up for abusive or fraudulent purposes.

The anti-abuse check gives the competent authority an additional three months for assessment should they suspect that the cross-border operation is fraudulent, abusive or in use for criminal purposes. However, it is difficult for any authority to detect an abusive or fraudulent 
cross-border operation in practice, the scope of this abuse check will become clearer during the implementation period.

Next to the above provisions, we can find that the Directive pays a special attention to the protection of owners, creditors and employees.

In relation to owners, apart from the right to approve in the general meeting the conversion of the company, they have the right to be informed of their new right to dispose of their shares for adequate cash compensation in case they oppose the conversion.

In the case of creditors with claims due before the draft terms are disclosed, are to be provided with the appropriate system of interests' protection, and in case of dissatisfaction with the terms proposed, may apply to the appropriate authority for satisfactory safeguards.

Still and all, particular interest is paid to the employee's protection. They are to be consulted regarding the company conversion and they also benefit from advisory rights. Additionally, employee participation is also the subject of a scheme in which they can exercise influence on the management/ supervisory board appointments, right which cannot be circumvented.

By the same token, the processes regarding the other two operations, cross-border mergers and divisions, are largely similar. The Directive added/amended in these cases articles regarding: the report of the administrative/supervisory board to the members and employees, the report; the independent expert report; the approval of the general meeting and the protection of the three groups of stakeholders, together with the existence of a pre-merger certificate and a pre-division certificate respectively. In the case of divisions, the Directive sets forth clarifications regarding full and partial divisions, leaving out the case of division by absorption.

In conclusion, we can summarize that the dynamics of case law on freedom of establishment of companies have forced the European legislator to issue a Directive which introduces a new chapter for cross-border operations, jointly with various parallels regarding the procedural rules, but still a general, broad, procedural part and we have to wait for the implementation of the objectives in order to draw a final conclusion if the Member States have used the opportunity to introduce and alter national rules so as to make the subject more structured and clearer or they placed new administrative obstacles for the transfer of seat of companies.

\section{References}

Alexandropoulou, A. (2021, April). Protection of members and creditors after the Mobility Directive: challenges in the implementation, In ERA Forum, 22(1), 9-20, Springer Berlin Heidelberg.

Behrens, P. (2000). International Company Law in view of the Centros Decision of the ECJ, European Business Organization Law Review (EBOR), 1(1), 125-146.

Borg-Barthet, J. (2009). II. European Private International Law of Companies after Cartesio, International \& Comparative Law Quarterly, 58(4), 1020-1028.

Borg-Barthet, J. (2013). Free at last? Choice of corporate law in the EU following the judgment in Vale, International \& Comparative Law Quarterly, 62(2), 503-512.

Chirieac, R. M. (2020). The future of cross border mergers in the light of the new European Union provisions. Their implementation in Romania, Tribuna Juridică , 10(2), 279-288.

Craig, P., de Burca, G. (2020). EU law: text, cases, and materials, $6^{\text {th }}$ Ed, Oxford University Press, Oxford.

Dumitru, O. I. (2020). The Transfer of Seat of Companies within the European Single Market, Law Review, 10(1), 70-95. 
Ene, C. (2020). The Cross-Border Conversion-A Possible Solution for the Mobility of Companies in European Union, Perspectives of Law and Public Administration, 9(1), 54-57.

García, R. A. (2020). La Directiva sobre transformaciones, fusiones y escisiones transfronterizas: regulación y facilitación de la movilidad de sociedades dentro de la Unión Europea, La Ley Unión Europea, 8(77), 18-26.

Gerner-Beuerle, C., and Schillig, M. (2010). The mysteries of freedom of establishment after Cartesio, International \& Comparative Law Quarterly, 59(2), 303-323.

PICBE |

929

Gerner-Beuerle, C., Mucciarelli, F. M., Schuster, E., \& Siems, M. (2018). Cross-border reincorporations in the European Union: the case for comprehensive harmonization, Journal of Corporate Law Studies, 18(1), 1-42.

Ebke, W.F. (2002). The "Real Seat" Doctrine in the Conflict of Corporate Laws, The International Lawyer, 36, 1015-1037.

Fabris, D. (2019). European Companies "Mutilated Freedom". From the Freedom of Establishment to the Right of Cross Border Conversion, European Company Law, 16(4), 109-123.

Fillers, A. (2020). Free Movement of Companies After the Polbud Case, European Business Organization Law Review, 21, 571-590.

Khan, A. (2011). Corporate Mobility under Article 49 TFEU: A Question of Means, not Ends., European Business Law Review, 6, 847-870.

Lombardo, S. (2019), Regulatory Competition in European Company Law. Where Do We Stand Twenty Years after Centros?, European Corporate Governance Institute (ECGI) - Law Working Paper No. 452/2019, 1-30.

Mucciarelli, F. M. (2008). Company 'emigration'and EC freedom of establishment: Daily Mail revisited, European Business Organization Law Review, 9(2), 268-295.

Pérez, A. N. (2020). El derecho de separación en las fusiones transfronterizas intracomunitarias como instrumento de protección del socio minoritario y las modificaciones introducidas por la directiva UE 2019/2121, Revista de derecho de sociedades, (59), 7.

Sánchez Barrios, J. L. (2020). Directiva (UE) 2019/2121 del Parlamento Europeo y del Consejo de 27 de noviembre de 2019 por la que se modifica la Directiva (UE) 2017/1132 en lo que atañe a las transformaciones, fusiones y escisiones transfronterizas [DOUE, L n. ${ }^{\circ}$ 321, de 12-XII-2019].

Soegaard, G. (2018). Cross-border Transfer and Change of Lex Societatis After Polbud, C-106/16: Old Companies Do Not Die... They Simply Fade Away to Another Country, European Company Law, 15(1), 21-24.

Stoican, A. (2020). The Voluntary Dissolution of a Limited Liability Company-A Way of Abusing the Law?, Perspectives of Law and Public Administration, 9(1), 65-69.

Ringe, W.G. (2005). No Freedom of Emigration for Companies?, European Business Law Review, 16(3), 621-642.

Ringe, W. G. (2013). Corporate Mobility in the European Union - a Flash in the Pan? An empirical study on the success of lawmaking and regulatory competition, European Company and Financial Law Review, 10(2), 230-267.

Wulf-Henning, R. (2003). From Centros to Ueberseering: Free Movement of Companies, Private International Law, and Community Law, The International and Comparative Law Quarterly, 52(1), 177-208.

Wymeersch, E. (2003). The Transfer of the Company's Seat in European Company Law, ECGI Working Papers Series in Law, Issue 8. 